\title{
KEWENANGAN MAHKAMAH PARTAI DALAM PENYELESAIAN \\ KONFLIK INTERNAL PARTAI POLITIK LOKAL DI ACEH \\ BERDASARKAN UNDANG-UNDANG NOMOR 2 TAHUN 2011 TENTANG PARTAI POLITIK
}

\section{THE AUTHORITY OF THE PARTY COURT IN THE COMPLETION OF THE INTERNAL CONFLICT OF LOCAL POLITICAL PARTIES IN ACEH BASED ON LAW NUMBER 2 OF 2011 CONCERNING POLITICAL PARTIES}

\author{
Jamaluddin 1 \\ ${ }^{1}$ Universitas Malikussaleh Cot Teungku Nie Reuleut Aceh Utara \\ Email: jamal_dhin@yahoo.com
}

\begin{abstract}
Political party disputes are a problem that has occurred lately. Law Number 2 of 2011 concerning Political Parties authorizes the resolution of conflicts to the Political Party Court in the event of a dispute by a Political Party. However, some of the decisions of the Party Court were not obeyed by the disputing parties. Therefore, how the role of the Political Party Court according to the law and it's the force of the decision in resolving Political Party disputes. Then, how the court functions resolve internal political party disputes. Settlement of internal disputes of a political party must be settled no later than 60 (sixty) days. The decision of a political party court is final and is binding internally in the case of disputes relating to management.Based on the background of the problem, this thesis aims to discuss the authority of the Local Political Party court in resolving internal political party conflicts and the legal force of the Local Political Party Court in resolving internal political party conflicts. This thesis uses the normative legal research method, which is a legal research method that looks at the content and in assessing the problem, namely the regulatory approach or the law. The Political Party Court or other designation formed by Political Parties has the authority to resolve internal political party conflicts. Therefore, based on party rules as regulated in the Articles of Association and by-laws, the settlement is left to the court of a political party or other designation in each Political Party. The Tuha Peut Council of party settles internal conflicts resolution of Local Political Parties in Aceh; among leaders, between leaders and members, and among members. Their decisions apply according to level and bind the disputing parties. The study suggests lawmakers revise Law Number 2 of 2011 immediately, especially Article 33. Accordingly, legal certainty is related to the functions and authority of the Political Party Court and does not involve the state in resolving internal political party conflicts.
\end{abstract}

Keywords: Authority, court, local political party 


\section{Intisari}

Perselisihan partai politik merupakan persoalan yang terjadi akhir-akhir ini. Undang-Undang Nomor 2 Tahun 2011 tentang Partai Politik memberi wewenang kepada Mahkamah Partai Politik apabila terjadi sengketa Partai Politik. Namun dalam kenyataannya, keputusan Mahkamah Partai tidak ditaati oleh para pihak yang bersengketa. Maka bagaimana peran Mahkamah Partai Politik menurut Undang-Undang Nomor 2 Tahun 2011 dan kekuatan hukum putusan Mahkamah Partai Politik dalam penyelesaian sengketa Partai Politik menentukan bahwa mahkamah partai politik berfungsi untuk menyelesaikan perselisihan internal Partai Politik. Penyelesaian perselisihan internal partai politik harus diselesaikan paling lambat 60 (enam puluh) hari. Putusan mahkamah partai politik bersifat final dan mengikat secara internal dalam hal perselisihan yang berkenaan dengankepengurusan. Berdasarkan latar belakang masalah tesis ini bertujuan untuk membahas mengenai kewenangan mahkamah Partai Politik Lokal dalam penyelesaian konflik internal Partai Politik dan kekuatan hukum Mahkamah Partai politik Lokal dalam penyelesaian konflik internal Partai Politik. Tesis ini menggunakan metode penelitian hukum normatif yaitu metode penelitian hukum yang melihat tentang isi dan dalam mengkaji permasalahan, yaitu pendekatan peraturan atau undang-undang. Mahkamah Partai Politik atau sebutan lain yang dibentuk oleh Partai Politik berkeenangan menyelesaikan konflik internal partai politik, maka secara ketentuan partai sebagaimana diatur dalam Anggaran Dasar (AD) maupun Anggaran Rumah Tangga (ART) penyelesaiannya diserahkan kepada mahkamah partai politik atau sebutan lain di setiap Partai Politik. Penyelesaian konflik internal Partai Politik Lokal di Aceh yang berhubungan dengan konflik antara pimpinan dengan pimpinan, pimpinan dengan anggota dan anggota dengan anggota diselesaikan oleh Majelis Tuha Peut menurut tingkatan dan putusan Majelis Tuha Peut mengikat para pihak yang berselisih. Direkomendasikan agar pembentuk undang-undang segera melakukan revisi Undang-Undang Nomor 2 Tahun 2011 terutama Pasal 33, agar terciptanya kepastian hukum terkait fungsi dan wewenang Mahkamah Partai Politik serta tidak melibatkan negara dalam penyelesaian konflik internal Partai Politik.

Kata kunci: Kewenangan, mahkamah, partai politik lokal

\section{A. Latar Belakang Masalah}

Dalam suatu negara yang menganut sistem demokrasi, hak-hak untuk berserikat, berkumpul dan mengeluarkan pikiran merupakan bagian dari upaya untuk mewujudkan kehidupan berbangsa yang kuat dalam Negara Kesatuan Republik Indonesia (NKRI) yang merdeka, bersatu, berdaulat, demokratis dan berazaskan hukum. Melalui kebebasan yang bertanggung jawab, segenap warganegara memiliki hak untuk berkumpul dan berserikat guna mewujudkan cita-cita politiknya secara nyata. Kesetaraan merupakan prinsip yang memungkinkan segenap warga negara berpikir dalam kerangka kesamaan sekalipun kedudukan, fungsi dan peran masing-masing berbeda. Kebersamaan 
merupakan wahana untuk mencapai tujuan berbangsa dan bernegara sehingga segala bentuk tantangan lebih mudah dihadapi. ${ }^{1}$

Partai Politik dapat mengambil peran penting dalam menumbuhkan kebebasan, kesetaraan dan kebersamaan sebagai upaya untuk membentuk bangsa dan negara yang padu. Di dalam sistem politik demokrasi, kebebasan dan kesetaraan tersebut diimplementasikan agar dapat merefleksikan rasa kebersamaan yang menjamin terwujudnya cita-cita kemasyarakatan secara utuh. Disadari bahwa proses menuju kehidupan politik yang memberikan kepada partai politik sebagai aset nasional berlangsung berdasarkan prinsip perubahan dan kesinambungan yang makin lama makin menumbuhkan kedewasaan dan tanggung jawab berdemokrasi².

Undang-Undang Dasar Negara Republik Indonesia Tahun 1945 sebagai konstitusi negara Indonesia, telah memberikan jaminan yang tegas dalam hal kemerdekaan untuk berserikat. Pasal 28E ayat (3) Undang-Undang Dasar Negara Republik Indonesia Tahun 1945 menegaskan bahwa "Setiap Orang berhak atas kebebasan berserikat, berkumpul, dan mengeluarkan pendapat". Ketentuan dalam Pasal 28E ayat (3) tersebut mengandung jaminan kemerdekaan berserikat yanglebih tegas dibandingkan dengan ketentuan Pasal 28 yang berasal dari rumusan Undang-Undang Dasar Negara Republik Indonesia Tahun 1945 sebelum perubahan. Sebagai bentuk pengaturan lebih lanjut dari ketentuan UndangUndang Dasar Negara Republik Indonesia Tahun 1945 mengenai jaminan kemerdekaan berserikat, maka dibentuklah beberapa peraturan perundangundangan yang mengatur kemerdekaan berserikat bagi warga Negara.

Khusus untuk peraturan perundang-undangan yang mengatur masalah partai politik, telah ada Undang-Undang Nomor 2 Tahun 2008 tentang Partai Politik juncto Undang-Undang Nomor 2 Tahun 2011 tentang Perubahan Atas Undang-Undang Nomor 2 Tahun 2008 tentang Partai Politik.

Tanpa Partai Politik dan organisasi-organisasi kemasyarakatan yang bebas dan merdeka, suara rakyat tidak akan dapat disalurkan untuk mempengaruhi proses-proses penentuan kebijakan yang berkaitan dengan kepentingan bersama dalam kehidupan bermasyarakat dan bernegara. Dalam kerangka politik, organisasi kemasyarakatan, dan lembaga swadaya masyarakat dapat dikatakan serupa. Hanya bedanya, Partai Politik berurusan langsung dengan kebijakan bernegara, sedangkan organisasi kemasyarakatan dan lembaga swadaya masyarakat hanya berhenti pada perjuangan wacana publik atau tindakan-tindakan konkrit di luar konteks organisasi negara . Organisasi nonpolitik tidak dapat dan tidak memegang kewenangan hukum untuk menentukan keputusan-keputusan kenegaraan. Namun, partai politik dapat melakukannya melalui perantaraan orang-orang yang berhasil mereka perjuangkan untuk menduduki jabatan-jabatan

\footnotetext{
${ }^{1}$ Franz Magnis Suseno, Etika Politik; Prinsip-Prinsip Moral Dasar Kenegaraan Modern, Cetakan Kelima, Gramedia Pustaka Utama, Jakarta, 1999, hlm. 289

2 Soedarsono, Mahkamah Konstitusi Sebagai Pengawal Demokrasi: Penyelesaian Sengketa Hasil Pemilu 2004 oleh Mahkamah Konstitusi RI, Jakarta: Sekretariat Jenderal dan Kepaniteraan Mahkamah Konstitusi RI, 2005, hlm. 11
} 
kenegaraan yang dipilih (elected official) ${ }^{3}$.

Partai politik lokal juga telah diamanatkan dalam Undang-Undang Nomor. 11 Tahun 2006 tentang Pemerintahan Aceh biapun sangat bertentangan dengan Undang-Undang Nomor. 2 Tahun 2011 tentang Partai Politik. Dibuktikan dengan adanya perbedaan definisi mengenai pembentukan partai politik di antara keduanya. Menurut Undang-Undang No. 11 Tahun 2006 tentang Pemerintahan Aceh menyatakan bahwa pembentukan partai politik dapat dilakukan melalui pemilihan umum dan pemilihan kepala daerah. Sedangkan menurut UndangUndang No. 2 Tahun 2011 tentang partai politik menjelaskan secara jelas bahwa pembentukan partai politik hanya dapat dilakukan melalui pemilihan secara umum. Dari kedua perbedaan undang-undang ini menjadi dilema bagi perkembangan partai politik lokal di Provinsi Aceh sangat tidak jelas arah politiknya. $^{4}$

Selama ini yang menjadi penyebab keinginan Aceh untuk merdeka adalah mereka ingin diperlakukan sama dengan daerah lain. Kini dengan dibentuknya partai politik lokal masyarakat. Aceh merasa diperhatikan aspirasinya sehingga ancaman terhadap disintegrasi bangsa akan berkurang. ${ }^{5}$

Eksistensi partai politik lokal di Aceh memang tidak menjadi perdebatan yuridis lagi ketika Undang-Undang Nomor. 11 Tahun 2006 (Undang-Undang Pemerintahan Aceh) dan Peraturan Pemerintah Nomor. 22 Tahun 2007 tentang Partai Politik Lokal di Aceh telah mengamanatkannya. Kehadirannya juga merupakan bagian dari road map to peace process di Aceh seperti yang tertuang dalam kesepakatan Helsinki, 15 Agustus $2005 .^{6}$

Wewenang dan peran Tuha Peut sangat vital dalam menentukan arah kebijakan internal partai dalam mengambil keputusan. Isi dari Bab II Pasal 6 tentang Majelis Tuha Peut tersebut sebagai berikut:

1. Majelis Tuha Peut Aceh adalah unsur Dewan Pimpinan Partai untuk seluruh Aceh yang berwenang membuat rancangan keputusan yang berhubungan dengan hal-hal yang mendasar dan strategis untuk dilaksanakan oleh pimpinan Partai Untuk seluruh Aceh.

2. Majelis Tuha Peut Aceh ditentukan berdasarkan keilmuan melalui Musyawarah seluruh Aceh.

3. Majelis Tuha Peut Aceh dipimpin oleh seorang Ketua dan sekretaris.

4. Ketua Tuha Peut di tentukan oleh Rapat Majelis Tuha Peut Aceh.

Oleh karena itu setiap keputusan Partai Aceh (PA) dapat diselesaikan oleh Mahkamah Partai (Tuha Peut) sendiri melalui dialog yang dimediasi oleh petinggi partai sesuai dengan Anggaran Darar Rumah Tangga Partai (ART) atau sesuai

\footnotetext{
${ }^{3}$ Jimly Asshiddiqie, Pokok-Pokok Hukum Tata Negara Indonesia, Bhuana Ilmu Populer, Jakarta, 2007, hlm. 713

${ }^{4}$ Jimly Asshiddiqie, Kemerdekaan Berserikat, Pembubaran Partai Politik, dan Mahkamah Konstitusi, (Jakarta: Konstitusi Press, 2005), hal 45.

${ }^{5}$ Ibid., 57-58.

${ }^{6}$ http//opinibebas.epajak.org/politik/partai-politik-lokal-710/ Teuku Kemal Fasya 'Partai Lokal' diakses 7 Juni 2008.
} 
dengan Undang-Undang. ${ }^{7}$

Berdasarkan Pasal 32 Undang-Undang Nomor 2 Tahun 2011 tentang Perubahan Atas Undang-Undang Nomor 2 Tahun 2008 tentang Partai Politik, menyebutkan $:^{8}$

(1) Perselisihan Partai Politik diselesaikan oleh internal Partai Politik sebagaimana diatur di dalam AD dan ART.

(2) Penyelesaian perselisihan internal Partai Politik sebagaimana dimaksud pada ayat (1) dilakukan oleh suatu mahkamah Partai Politik atau sebutan lain yang dibentuk oleh Partai Politik.

(3) Susunan mahkamah Partai Politik atau sebutan lain sebagaimana dimaksud pada ayat (2) disampaikan oleh Pimpinan Partai Politik kepada Kementerian.

(4) Penyelesaian perselisihan internal Partai Politik sebagaimana dimaksud pada ayat (2) harus diselesaikan paling lambat 60 (enam puluh) hari.

(5) Putusan mahkamah Partai Politik atau sebutan lain bersifat final dan mengikat secara internal dalam hal perselisihan yang berkenaan dengan kepengurusan.

Sedangkan Pasal 33 dalam Undang-Undang Nomor 2 Tahun 2011 tentang Perubahan Atas Undang-Undang Nomor 2 Tahun 2008 tentang Partai Politik, tercantum yaitu $:^{9}$

(1) Dalam hal penyelesaian perselisihan sebagaimana dimaksud dalam Pasal 32 tidak tercapai, penyelesaian perselisihan dilakukan melalui pengadilan negeri.

(2) Putusan pengadilan negeri adalah putusan tingkat pertama dan terakhir, dan hanya dapat diajukan kasasi kepada Mahkamah Agung.

(3) Perkara sebagaimana dimaksud pada ayat (1) diselesaikan oleh pengadilan negeri paling lama 60 (enam puluh) hari sejak gugatan perkara terdaftar di kepaniteraan pengadilan negeri dan oleh Mahkamah Agung paling lama 30 (tiga puluh) hari sejak memori kasasi terdaftar di kepaniteraan Mahkamah Agung.

\section{B. Rumusan Masalah}

Bertitik tolak dari latar belakang masalah di atas, permasalahanpermasalahan yang akan dikaji dalam kaitan penelitian ini adalah sebagai berikut:

1. Bagaimanakah kewenangan Mahkamah Partai Politik Lokal dalam penyelesaian konflik internal Partai?

2. Bagaimanakah kekuatan hukum Putusan Mahkamah Partai Politik Lokal terhadap penyelesaian konflik internal Partai?

\section{Tujuan Penelitian}

Penelitian ini bertujuan untuk menganalisa dan mengetahui lebih dalam tentang :

a. Kewenangan Mahkamah Partai Politik dalam penyelesain konflik

\footnotetext{
${ }^{7}$ M. Alfi Syahri, Peran dan Wewenang Majelis Tuha Peut, Jurnal Ilmiah Mahasisa Fisip Unsyiah Volume 3 , Nomor 1-22 : 1-26 Juni 2018 Hal, 12-13

8 Republik Indonesia, Undang-Undang Nomor 2 Tahun 2011 tentang Perubahan Atas Undang-Undang Nomor 2 Tahun 2008 tentang Partai Politik, LN No.8, TLN No. 5189, Pasal 32 ${ }^{9}$ ibid
} 
internal partai.

b. Kekuatan hukum Putusan Mahkamah Partai Politik terhadap penyelesaian konflik internal Partai.

\section{Metode Penelitian}

1. Jenis Penelitian

Jenis metode penelitian yang digunakan dalam penelitian ini adalah metode penelitian kajian kepustakaan (Library Research), yang bersifat yuridis normatif yaitu penelitian yang mengacu pada penyelesaian konflik pada partai politik menurut ketentuan pasal 32 dan 33 Undang-Undang Nomor 2 Tahun 2011 tentang partai politik. Metode penelitian normatif, karena yang akan diteliti adalah kewenangan Mahkamah Partai dalam penyelesaian konflik internal partai politik untuk mencapai kesepakatan bersama, dan dimana penelitian tersebut menggunakan data yang diperoleh dari bahan hukum primer dan skunder.

\section{Sifat Penelitian}

Penelitian ini bersifat preskiptif-analitis, karena prosedur pemecahan masalah yang diselidiki dengan menggambarkan dan mendiskripsikan keadaan subyek/obyek penelitian, dalam hal ini partai politik yaitu : konflik internal partai pada saat sekarang berdasarkan fakta-fakta yang tampak atau sebagaimana adanya.

\section{Pendekatan Penelitian}

Penelitian ini menggunakan metode pendekatan yuridis normatif, karena menggunakan data sekunder sebagai data utama. ${ }^{10}$ Perolehan data dilakukan melalui studi kepustakaan, yaitu suatu teknik pengumpulan data dengan memanfaatkan berbagai literatur yang dapat memberikan landasan teori yang relevan dengan masalah yang akan dibahas antara lain dapat bersumber dari peraturan perundang-undangan yang berlaku di Indonesia, literatur-literatur, karya-karya ilmiah, makalah, artikel, media massa, serta sumber data sekunder lainnya yang terkait dengan permasalahan yang akan dibahas mengenai Penyelesaian Perselisihan Internal Partai Politik.

\section{Sumber Bahan Hukum}

Dalam penelitian hukum normatif maka yang digunakan sebagai sumber bahan hukum adalah bahan pustaka. Apabila dilihat dari sudut sifat informasi yang diberikannya bahan pustaka dapat dibagi dalam 2 kelompok sebagai berikut $^{11}$

a. Seminar dan lain-lain, laporan penelitian, majalah, desertasi/tesis. Bahan hukum primer, yakni bahan pustaka yang berisikan pengetahuan ilmiah yang baru atau mutakhir, ataupun pengertian baru tentang fakta yang diketahui maupun mengenai suatu gagasan (ide). Bahan/sumber primer ini mencakup : buku, kertas kerja lokakarya

b. Bahan/sumber sekunder, yaitu bahan pustaka yangberisi informasi

10 Ronny Hanitijo Soemitro, Metode Penelitian Hukum, Ghalia Indonesia, Jakarta, 1985,hlm.93.

${ }^{11}$ Ibid, hal 29 
tentang bahan primer. Bahan/sumber sekunder ini antara lain mencakup: abstrak, indeks, bibliografi, penerbitan pemerintah dan acuan lainnya.

\section{Analisis Bahan Hukum}

Analisis bahan Hukum adalah suatu tahapan yang sangat penting dalam suatu penelitian sehingga akan mendapakan hasil yang akan mendekati kebenaran yang ada. Dalam penulisan tesis ini digunakan teknik analisis kualitatif, yaitu data yang dikumpul dituangkan dalam bentuk uraian logis dan sistematis, bahan hukum yang diperoleh kemudian ditafsirkan pada peraturan perundangundangan dan doktrin-doktrin hukum yang berhubungan dengan masalah yang diteliti. selanjutnya dianalisis untuk memperoleh kejelasan masalah kumudian ditarik kesimpulan.

\section{E. Hasil Penelitian dan Pembahasan}

1. Kewenangan Mahkamah Partai Politik Lokal dalam Penyelesaian Konflik Internal Partai

a. Tujuan Pembentukan Partai Politik lokal

Kehadiran Partai Politik Lokal di Aceh merupakan suatu bukti perkembangan demokrasi di Indonesia. Dengan hadirnya partai politik lokal merupakan tambahan sarana untuk penyampaian aspirasi masyarakat. Khususnya di Aceh, kehadiran partai politik lokal memberikan harapan hidupnya demokratisasi di Aceh. Saat ini masyarakat Aceh sangat leluasa dalam menunjukkan sikap politiknya melalui Partai politik Lokal yang terbentuk di Aceh.

Munculnya Partai Politik Lokal merupakan hasil kesepakatan perdamaian di Aceh yang merupakan rangkaian penyelesaian konflik Aceh dengan pemerintah Indonesia melalui penandatanganan Memorandum of Unterstanding Helsinki . Aceh diberikan wewenang untuk dapat hidup mandiri, baik itu dibidang ekonomi, politik dan hukum secara politik Aceh diberikan wewenang untuk mendirikan partai politik lokal.

Pembentukan partai politik lokal itu sendiri tidak serta merta dapat didirikan begitu saja, tetapi pembentukan partai politik lokal itu sendiri memiliki persyaratan-persyaratan yang harus dipenuhi oleh masyarakat yang ingin membentuk partai politik lokal di Aceh. Syarat-syarat pembentukan partai politik lokal di Aceh dapat kita lihat Peraturan Pemerintah Republik Indonesia Nomor 20 Tahun 2007 tentang partai politik lokal di Aceh. Syarat-syarat tersebut sudah diatur sedemikian rupa didalam pasal-pasal Peraturan Pemerintah Republik Indonesia Nomor 20 Tahun 2007 tentang partai politik lokal di Aceh, antara lain yaitu :

b. Tata cara pendaftaran dan Pengesahan sebagai badan hukum. ${ }^{12}$

1) Partai politik di Aceh yang sudah memenuhi persyaratan pendirian dan pembentukan harus didaftarkan pada dan disahkan sebagai badan hukum oleh Kepala Kantor Wilayah Departemen di Aceh.

12 Lihat Pasal 2 Peraturan Pemerintah Nomor 20 Tahun 2007 Tentang Partai Politik Lokal 
2) Partai politik lokal dimana dimaksud pada ayat (1) menyampaikan berkas yang dipersyaratakan untuk pendaftaran partai politik dan pengesahan badan hukum dengan surat pengantar dari pimpinan partai politik lokal kepada Kepala Kantor Wilayah Departemen di Aceh dengan menyertakan antara lain :

a) akta notaris pendirian partai politik lokal yang memuat, anggaran dasar, anggaran rumah tangga, dan susunan kepengurusannya.

b) nama, lambang dan tanda gambar; dan

c) alamat kantor tetap partai politik lokal

c. Partai politik lokal dimana dimaksud pada ayat (1) mempunyai kepengurusan paling edikit 50\% (lima puluh persen) dari sejumlah kabupaten/kota di Aceh dan 25\% (dua puluh lima persen) dari jumlah kecamatan pada setiap kabupaten/kota yang bersangkutan dengan memperhatikan keterakilan perempuan paling sedikit 30\% (tiga puluh persen)

d. Nama, lambang dan tanda gambar sebagaimana dimaksud pada ayat 2 (dua) huruf $\mathrm{b}$ tidak mempunyai persamaan pada pokoknya atau keseluruhannya dengan lambang negara, lambang lembaga negara, lambang pemerintah, lambang pemerintah daerah nama, lambang dan tanda gambar partai politik atau partai politik lokal lainnya.

e. Dalam hal nama, lambang atau tanda gambar suatu partai politik lokal pada saat pendaftaran terdapat persamaan dengan partai politik lokal lainnya atau partai politik, maka partai politik atau partai politik lokal yang terdaftar lebih awal yang berhak menggunakan nama, lambang atau tanda gambar tersebut

f. Kantor dan alamat tetap partai politik lokal sebagimana dimaksud pada ayat (2) huruf c dibuktikan dengan dokumen yang sah.

g. Ketentuan sebagaimana dimaksud pada ayat (6) berlaku untuk semua tingkatan kepengurusan partai politik lokal di Aceh dan kabupaten/kota di Aceh.

Langkah selanjutnya, dokumen pendafran partai politik lokal sebagaimana yang dimaksud dalam pasal (2) diteliti dan/atau diverifikasi oleh Kantor Wilayah Departemen di Aceh. Lalu partai politik lokal yang memenuhi persyaratan setelah diteliti dan/atau verifikasi sebagaimana dimaksud ayat (1), didaftar dalam buku pendaftaran partai politik lokal pada Kantor Wilayah Departemen di Aceh. Untuk pelaksanaan penelitian dan/atau verifikasi serta pendaftaran sebagaimana dimaksud pada ayat (1) dan ayat (2) diselesaikan paling lambat 30 (tiga puluh) hari sejak dokumen persyaratan dinyatakan lengkap. ${ }^{13}$

Pembentukan Partai Politik lokal di Aceh dibagi menjadi dua yaitu secara umum dan secara khusus. Secara umum tujuan partai politik lokal adalah untuk mewujudkan cita-cita nasional bangsa indonesia sebagaimana dinaksud dalam Undang-Undang Dasar Negara Republik Indonesia 1945, mengembangkan kehidupan demokrasi berdasarkan pancasila dengan menjunjung tinggi

${ }^{13}$ Ibid Pasal 3 
keudaulatan rakyat dalam Negara Kudaulatan Republik Indonesia dan meujudkan kesejahteraan bagi seluruh masyarakat Aceh. Sedangkan tujuan partai politik lokal yang bersifat khusus adalah meningkatkan partisispasi politik masyarakat Aceh dalam rangka penyelenggaraan pemerintahan daerah dan memperjuangkan citacita partai politik lokal dalam kehidupan bermasyarakat, bebangsa dan bernegara sesuai kekukhususan dan keistimeaan Aceh. Baik tujuan umum maupun tujuan khusus itu dilaksanakan secara konstutusional artinya partai politik lokal sebagaimana partai politik nasional dilarang untuk melakukan kegiatan yang bertentangan dengan pancasila dan Undang-Undang Dasar 1945 atau Peraturan Perundang Undangan dan melakukan kegiatan yang membahayakan keutuhan Negara Kesatuan Republik Indonesia. ${ }^{14}$

\section{Pembentukan Mahkamah Partai Politik}

Pembentukan mahkamah partai politik didasarkan pada dilakukannya perubahan terhadap Undang-Undang Partai Politik. Awalnya belum ada alternatif penyelesaian sengketa internal partai politik melalui mahkamah partai politik sehingga setelah berubahnya Undang-Undang Partai Politik maka dibentuklah suatu badan peradilan partai yang disebut sebagai mahkamah partai politik

Tata cara pembentukan mahkamah Partai Politik diatur dalam Pasal 32 ayat (3) Undang-Undang Nomor 2 Tahun 2011 tentang Perubahan Atas UndangUndang Nomor 2 Tahun 2008 tentang Partai Politik, yang berbunyi: “ Susunan mahkamah Partai Politik atau sebutan lain sebagimana dimaksud pada ayat (2) disampaikan oleh pimpinan Partai Politik kepada kementerian”. Sebagaimana diketahui, mahkamah Partai Politik adalah "pengadilan khusus" untuk perselisihan Partai Politik yang diberikan kewenangan untuk mengadili perkara perselisihan Partai Politik, yakni: (1) Perkara perselisihan yang berkenaan dengan kepengurusan (bidang perdata/administrasi), (2) Perkara pelanggaran terhadap hak anggota Partai Politik (perdata), (3) Perkara pemecatan tanpa alasan yang jelas (perdata), administrasi), (4) Perkara pertanggungjawaban keuangan (pidana), serta (6) Perkara keberatan terhadap keputusan Partai Politik (administrasi).

Kewenangan mahkamah Partai Politik yang dilakukan dalam hal mengadili perselisihan Partai Politik merupakan kewenangan yang diperoleh secara atribusi yang secara normatif diatur dalam Undang-Undang Nomor 2 Tahun 2011. Wewenang terdiri atas sekurang-kurangnya tiga komponen, yaitu pengaruh, dasar hukum, dan konformitas hukum. Komponen pengaruh, yaitu penggunaan wewenang dimaksudkan untuk mengendalikan perilaku subjek hukum. Komponen dasar hukum ialah wewenang itu harus ditunjuk dasar hukumnya, dan komponen konformitas hukum mengandung adanya standar wewenang yaitu standar (semua jenis wewenang) serta standar khusus. ${ }^{15}$

Dalam kaitannya dengan wewenang sesuai dengan konteks pembahasan ini, standar wewenang adalah kewenangan mahkamah Partai Politik dibidang mengadili perkara perselisihan Partai Politik. Hakim mahkamah Partai Politik

14 Pasal 77 ayat (1) dan ayat (2) Undang-Undang Nomor 11 Tahun 2006 tentang Pemerintah Aceh.

15 Philipus M. Hadjon, Penataan Hukum Administrasi, Tahun 1997/1998 tentang Wewenang, Fakultas Hukum Unair, Surabaya, hlm. 2. 
dalam mengadili perkara perselisihan Partai Politik memperoleh kewenangan dari Partai Politik, sedangkan hakim adalah pengurus Partai Politik, yakni bagian dari partai. Seharusnya dalam mengadili perkara perselisihan Partai Politik harus memperoleh kewenangan tersebut dari negara dan negara diwakili oleh kepala negara. ${ }^{16}$

\section{Peran dan Wewenang Mahkamah Partai Politik Lokal}

Kehadiran Mahkamah Partai di Indonesia merupakan gagasan dari Dewan Perwakilan Rakyat (DPR) atas kesepakatan bersama pemerintah, terwujud dengan dibentuknya Undang-Undang Nomor 2 Tahun 2011 atas perubahan UndangUndang Nomor 2 Tahun 2008 Tentang Partai Politi. Sebagaimana tujuan dari undang-undang partai politik ini ialah, untuk mewujudkan penataan dan penyempurnaan partai politik, yang pada prinsipnya membangun partai yang terpola dan sistematis, sehingga, partai dapat mengoptimalkan fungsi dalam kehidupan bermasyarakat, berbangsa dan bernegara. Hasil dari perubahan Undang-Undang Partai Politik ini, ialah mengenai persoalan yang mendasar terhadap kemandirian partai politik di Indonesia, hal itu juga disebutkan tempo lalu yang dimuat dalam sebuah media massa, sehingga dapat mengrangkum yakni tentang penjelasan wakil Ketua Komisi II DPR RI periode 2009-2014 Ganjar Pranowo, mengenai Rancangan Undang-Undang (RUU) Perubahan UndangUndang Nomor 2 Tahun 2008 Tentang Partai politik. ${ }^{17}$

Peran dan kewenangan Majelis Tuha Peut Partai Aceh telah diatur dalam ADRT Partai Aceh dimana Majelis Tuha Peut memiliki peran dan wewenang sebagai pembuat aturan atau pengambil kebijakan di dalam Partai Aceh ada beberapa dari Mantan Tuha Peuet Partai Aceh yaitu Zakaria Saman yang mengatakan bahwa dulu Tuha Peut di Partai Aceh sangat dominan perannya saat pertama Partai Aceh berdiri. Dimana banyak hal-hal yang telah dilakukan oleh Majelis Tuha Peut contohnya penunjukan calon Gubernur Aceh dari Partai Aceh dimana merupakan wewenang dan kekuasaan dari Majelis Tuha Peuet (Mahkamah Partai) dalam melakukan penunjukan tersebut dimana saat itu salah satunya penunjukan Zaini Abdullah dan Muzakir Manaf menjadi Calon Gubernur dan wakil Gubernur. ${ }^{18}$

Fakrul Razi berpendapat bahwa seharusnya rancangan aturan-aturan yang mendasar didalam Partai Aceh itu semua dibuat oleh Majelis Tuha Peuet akan tetapi hal tersebut tidak begitu berjalan di Partai Aceh saat ini salah satu faktor yang membuat hal tersebut dikarenakan saat ini Majelis Tuha Peuet yang pertama adalah orang-orang tua dari Partai Aceh yang terdiri dari empat orang sekarang tinggal satu orang yaitu Malek Mahmud Al Haytar, dimana saat ini dua anggota Majelis Tuha Peut Partai Aceh telah memutuskan keluar dari Partai Aceh karena ikut pemilihan Gubernur dari jalur independen sehingga memutuskan keluar dari

\footnotetext{
${ }^{16}$ Anwar Rachman, Hukum Perselisihan Partai Politik, Gramedia Pustaka Utama, Jakarta, 2016, hlm. 382 .

17 www.tribunnews.com Mahkamah Partai Jadi Hakim Partai politik, 13 Desember 2010, Diakses Tanggal 21 Januari 2016

${ }^{18}$ M.Alfi Syahri “Peran dan wewenang Majelis Tuha Peuet Dalam Membuat Kebijakan Partai Aceh” Skripsi Fakultas Ilmu Sosial dan Ilmu Politik, 2018. hlm 58
} 
Partai Aceh dan peran Malek Mahmud Al Haytar sangat dominan dan semua hal yang strategis atau aturan Partai Aceh dibuat atau dikeluarkan oleh ketua umum Dewan Pimpinan Partai Aceh sehingga Majelis Tuha Peuet Partai Aceh menjadi tidak berfungsi lagi saat ini. ${ }^{19}$

Untuk pelaksanaan Peraturan Pemerintah Nomor 20 tahun 2007 tentang Partai Politik Lokal di Aceh. Legitimasi pembentukan partai politik lokal di Aceh secara yuridis sudah sangat kuat yaitu dengan mempertimbangan Undang-undang Dasar 1945 Pasal 28 dan 18B. Selain itu juga, pembentukan partai politik lokal di Aceh tersebut, tidak melanggar asas penyusunan peraturan perundang-undangan yang terdapat dalam Undang-undang Nomor 12 tahun 2011 Tentang Pembentukan Peraturan Perundang-undangan,yaitu Supriore derogate Leg Inferiori (hukum yang kedudukannya lebih rendah tidak boleh bertentangan dengan hukum diatasnya) dan Lex specialis derogate lex general (hukum yang bersifat khusus dapat menyampingkan hukum yang bersifat umum). ${ }^{20}$

Meskipun keberadaan Peraturan Pemerintah Nomor 20 Tahun 2007 itu telah mencederai Undang-undang Nomor 2 tahun 2011 Tentang Partai Politik, namun pembentukan partai politik tersebut juga berlandaskan pada produk hukum tertinggi yakni Undang-undang Dasar 1945 pasal 28 tetang kebebasan berkumpul dan 18B tentang pengakuan negara terhadap kekhususan suatu Daerah. Dan pada asas yang kedua, kedudukan Undangundang Nomor 11 tahun 2006 Tentang Pemerintahan Aceh bersifat khusus (lex spesialis) sedangkan Undang-undang Nomor 2 tahun 2011Tentang Partai Politik bersifat umum. Jadi keberadan partai politik lokal di Aceh telah mendapat tempat di dalam sistem ketatanegaraan Republik Indonesia. $^{21}$

\section{Kekuatan Hukum Mahkamah Partai Politik Lokal dalam Penyelesaian Konflik Internal Partai \\ a. Putusan Mahkamah Partai Politik}

Terkait dengan putusan mahkamah Partai Politik, Pasal 32 Undang-Undang Nomor 2 Tahun 2011 tentang Perubahan Atas Undang-Undang Nomor 2 Tahun 2008 tentang Partai Politik, menyebutkan: ${ }^{22}$

(1) Perselisihan Partai Politik diselesaikan oleh internal Partai Politik sebagaimana diatur di dalam AD dan ART.

(2) Penyelesaian perselisihan internal Partai Politik sebagaimana dimaksud pada ayat (1) dilakukan oleh suatu mahkamah Partai Politik atau sebutan lain yang dibentuk oleh Partai Politik.

\section{${ }^{19}$ Ibid hlm 64}

${ }^{20}$ Lex specialis derogate lex general adalah asas penafsiran hukum yang menyatakan bahwa hukum yang bersifat khusus (lex specialis) mengesampingkan hukum yang bersifat umum (lex generalis)

21 Asda Rasida“ Partai Politik Lokal Aceh Dalam Sistem Ketatanegaraan Republik Indonesia "Jurnal Varia Justicia Volume 12 No.1 Maret 2016, Hlm 9-10

${ }^{22}$ Republik Indonesia, Undang-Undang Nomor 2 Tahun 2011 tentang Perubahan Atas Undang-Undang Nomor 2 Tahun 2008 tentang Partai Politik, LN No.8, TLN No. 5189, Pasal 32. 
(3) Susunan mahkamah Partai Politik atau sebutan lain sebagaimana dimaksud pada ayat (2) disampaikan oleh Pimpinan Partai Politik kepada Kementerian.

(4) Penyelesaian perselisihan internal Partai Politik sebagaimana dimaksud pada ayat (2) harus diselesaikan paling lambat 60 (enam puluh) hari.

(5) Putusan mahkamah Partai Politik atau sebutan lain bersifat final dan mengikat secara internal dalam hal perselisihan yang berkenaan dengan kepengurusan.

Sebagaimana bunyi Pasal 32 ayat (5) tersebut di atas, maka mengandung konsekuensi bahwa putusan mahkamah Partai Politik dalam hal perselisihan berkenaan dengan kepengurusan tidak dapat dilakukan upaya hukum lanjutan karena putusan mahkamah Partai Politik sudah bersifat terakhir dan mengikat (final and binding) seperti kewenangan yang melekat pada Mahkamah Konstitusi. Namun sayangnya, Pasal 33 ayat (1) Undang-Undang Nomor 2 Tahun 2011 tentang Perubahan Atas Undang-Undang Nomor 2 Tahun 2008 tentang Partai Politik masih memberikan upaya hukum lanjutan bagi pihak yang belum puas dengan putusan mahkamah Partai Politik, sebagaimana bunyi berikut; "(1) Dalam hal penyelesaian perselisihan sebagaimana dimaksud dalam Pasal 32 tidak tercapai, penyelesaian perselisihan dilakukan melalui pengadilan negeri."

Pasal 33 ayat (1) yang menyatakan : "Dalam hal penyelesaian perselisihan sebagaimana dimaksud dalam pasal 32 tidak tercapai, penyelesaian perselisihan dilakukan melalui Pengadilan Negeri". Ketentuan pasal 33 ayat (1) ini bertentangan dengan asas kepastian hukum bagi para pihak yang berperkara. Frasa "tidak tercapai" dalam pasal tersebut bersifat rancu, yakini bisa menganduung beberapa makna, diantaranya: (a) Persidangan atas perkara tersebut di Mahkamah Partai Politik tidak selesai secara tuntas. Dalam artian Hakim Mahkamah Partai Politik tidak berhasil mengambil putusan, atau (b) Mahkamah Partai Politik menolak mengadili perkara tersebut, atau (c) Para pihak yang berperkara tidak puas dengan putusan Mahkamah Partai.

Perkara politik bersifat khusus dan/atau spesifik. Pengadilan negeri pun akan menolak untuk menyidangkan perkara perselisihan partai politik karena adanya perintah UU agar terlebih dahulu menyidangkan di Mahkamah Partai Politik. Disamping itu, proses penyelesaian perkara perselisihan ini memakan waktu yang cukup lama. Oleh sebab itu, sebaiknya putusan Mahkamah Partai Politik terhadap perkara perselisihan partai politik bersifat final dan mengikat (Final and Binding). ${ }^{23}$

Tak hanya itu, Mahkamah Partai Politik adalah pengadilan politik yang tertinggi. Jadi, sangat tak pantas jika putusan mahkamah partai harus diajukan lagi sebagai gugatan di pengadilan negeri. Tidak terselesaikannya perselisihan partai sebagaimana ketentuan Pasal 32 akan membuka penafsiran bahwa pengadilan tinggi dapat menyelesaikan masalah kepengurusan partai. Padahal, sudah jelas disebutkan bahwa putusan Mahkamah Tinggi Partai bersifat terakhir dan mengikat. $^{24}$

\footnotetext{
${ }^{23}$ Anwar Rachman, Hukum Perselisihan Partai Politik, Gramedia Pustaka Utama, Jakarta, 2016, hlm. 515 .

${ }^{24}$ Ibid
} 
Secara universal, bunyi putusan hakim adalah yang : (1) menyatakan permohonan tidak dapat diterima, (2) menyatakan permohonan atau gugatan ditolak, (3) menyatakan bahwa gugatan dikabulkan. Ketika hakim menyatakan bahwa gugatan tidak dapat diterima atau niet ontvankelijke verklaard, sesungguhnya putusan seperti itu tidak menyentuh pokok perselisihan, tetapi menyangkut persoalan formalitas dan prosedur yang ditempuh. Situasi seperti inilah yang dikategorikan sebagai "tidak tercapai dalam perselihan" sebagaimana yang dimaksud dalam Pasal 3 ayat (1). Dan ini membuka pintu bagi forum pengadilan sebagai penyelesaian perselisihan. ${ }^{25}$

Jika putusan sudah ditetapkan, putusan bersifat final dan mengikat serta berkekuatan hukum tetap. Putusan yang telah berkekuatan hukum tetap akan memiliki tiga kekuatan, yakni : ${ }^{26}$

1. Kekuatan mengikat dalam arti res judicata yang disebut, yaitu pengadilan terikat untuk tidak melakukan peninjauan kembali terhadap apa yang sudah diputuskan dan terhadap setiap masalah lain yang dapat disimpulkan dari argument yang terkandung dalam putusan.

2. Kekuatan eksekutorial, yaitu putusan yang sudah berkekuatan hukum dengan kekuatan yang disebut dalam huruf (a) di atas memperoleh dasara untuk dilaksanakan, sebagaimana disebut dalam amar putusan.

3. Kekuatan bukti, yaitu putusan pengadilan yang sudah berkekuatan hukum tetap yang dapat diajukan sebagai bukti yang sempurna tentang hal yang dipertimbangkan didalamnya.

\section{b. Eksekusi Putusan Mahkamah Partai Politik}

Pada dasarnya, eksekusi atau pelaksanaan putusan adalah tindakan yang dilakukan secara paksa terhadap pihak yang kalah (Tergugat) dalam perkara apabila pihak yang kalah tersebut tidak patuh dan tunduk pada putusan pengadilan. Pada prinsipnya, hanya putusan yang telah memperoleh kekuatan hukum tetap (inkracht van gewijsde) yang dapat dilakukan. ${ }^{27}$ Dengan demikian, pada dasarnya putusan yang dapat dilakukan eksekusi adalah: ${ }^{28}$

1. Putusan yang telah memperoleh kekuatan hukum tetap (inkracht van gewijsde).

2. Dari putusan yang telah memperoleh kekuatan hukum tetap tersebut terkandung maksud hubungan hukum yang tetap (fixed) dan pasti antara pihak yang berperkara.

3. Karena hubungan hukum antara pihak yang berperkara sudah tetap dan pasti, hubungan hukum tersebut harus ditaati dan harus dipenuhi oleh pihak yang dihukum (tergugat).

Cara menaati dan memenuhi hukum-hukum yang ditetapkan dalam amar putusan yang telah memperoleh kekuatan hukum tetap adalah: dapat dilakukan

\footnotetext{
${ }^{25}$ Anwar Rachman, Op.Cit, Hlm. 516.

${ }^{26}$ Anwar Rachman, Op.Cit, Hlm. 517.

27 M. Yahya Harahap, Ruang Lingkup Permasalahan Eksekusi Bidang Perdata, Sinar Grafika, Jakarta, 2005, hlm. 7.

${ }^{28}$ Ibid
} 
secara sukarela oleh pihak tergugat dan bila enggan secara sukarela, dapat dilakukan dengan paksa dengan bantuan aparat kepolisian. ${ }^{29}$

Perkara-perkara yang menjadi kewenangan mahkamah Partai Politik secara umum dapat digolongkan menjadi 2 (dua) bagian, yakni: ${ }^{30}$

1. Perkara yang berkaitan dengan hak-hak anggota Partai Politik yang biasanya berkaitan dengan pemberhentian/pemecatan sebagai anggota Partai Politik untuk kepentingan PAW (Penggantian Antar Waktu) anggota DPR/DPRD.

2. Perkara yang berkaitan dengan kepengurusan Partai Politik.

Surat keputusan Partai Politik tentang kepengurusan Partai Politik ini banyak diperselisihkan apabila berkaitan dengan: ${ }^{31}$

1. Pendaftaran calon presiden/wakil presiden pada pemilu, baik sebagai pengusung maupun pendukung.

2. Pendaftaran calon gubernur/wakil gubernur pada pemilihan kepala daerah gubernur/wakil gubernur, baik sebagai pengusung maupun pendukung.

3. Pendaftaran calon bupati/wakil bupati, wali kota/wakil wali kota pada pemilihan kepala daerah kabupaten/kota, baik sebagai pengusung maupun pendukung.

4. Pendaftaran calon anggota legilatif DPR/DPRD pada pemilu legislatif.

Putusan mahkamah Partai Politik memang berlaku untuk internal Partai Politik yang bersangkutan, namun putusan mahkamah Partai Politik yang berkaitan dengan 4 (empat) perkara dimaksud, mau tidak mau, suka tidak suka, harus diaptuhi oleh pihak-pihak yang terkait. Untuk perkara kepengurusan Partai Politik, Putusan mahkamah Partai Politik tersebut dipakai dasar oleh KPU untuk mengetahui kepengurusan mana yang berhak untuk mengajukan calon presiden, gubernur, bupati/wali kota dan juga dipakai oleh kepolisian untuk pengamanan gedung atau acara-acara Partai Politik. ${ }^{32}$

Selain itu putusan mahkamah Partai Politik tersebut dipakai Kementerian Dalam Negeri, Pemerintah Provinsi, Pemerintah Kabupaten/Kota untuk mencairkan dana bantuan Partai Politik dan juga dipakai oleh Menteri Hukum dan HAM untuk kepengurusan Partai Politik. Putusan mahkamah Partai Politik yang berkaitan dengan pemberhentian anggota Partai Politik dipakai Presiden, KPU, dan Ketua DPR untuk memproses permohonan pergantian antarwaktu anggota DPR, begitu juga gubernur, bupati/wali kota serta KPU untuk memproses permohonan PAW (Penggantian Antar Waktu) anggota DPRD. Dengan demikian, jelaslah bahwa keputusan mahkamah Partai Politik bukan hanya berlaku untuk internal Partai Politik, namun juga berlaku untuk eksternal Partai Politik dan pihak yang terkait dengan permasalahan perselisihan Partai Politik itu. Secara umum, eksekusi putusan mahkamah Partai Politik tidak banyak kendala karena putusan mahkamah Partai Politik bersifat administratif yang eksekusinya tidak perlu bantuan aparat kepolisian sebagaiamana eksekusi perkara pidana. ${ }^{33}$ Eksekusi putusan dilakukan terhadap putusan yang sudah mempunyai kekuatan

\footnotetext{
${ }^{29}$ Ibid, hlm. 8.

${ }^{30}$ Anwar Rachman, Op.Cit. hlm. 366.

${ }^{31}$ Ibid

${ }^{32}$ Ibid. hlm. 367.

${ }^{33}$ Ibid
} 
hukum mengikat.

Sebagaimana bunyi Pasal 32 ayat (5) Undang-Undang Partai Politik, mengandung konsekuensi bahwa putusan mahkamah Partai Politik dalam hal perselisihan berkenaan dengan kepengurusan tidak dapat dilakukan upaya hukum lanjutan karena putusan mahkamah Partai Politik sudah bersifat terakhir dan mengikat (final and binding) seperti kewenangan yang melekat pada Mahkamah Konstitusi. Namun sayangnya, Pasal 33 Ayat (1) Undang-Undang tentang Partai Politik masih memberikan upaya hukum lanjutan bagi pihak yang belum puas dengan putusan mahkamah Partai Politik, sebagaimana bunyi berikut; "(1) Dalam hal penyelesaian perselisihan sebagaimana dimaksud dalam Pasal 32 tidak tercapai, penyelesaian perselisihan dilakukan melalui pengadilan negeri."

Mekanisme ini dengan sendirinya menganulir frasa "final dan mengikat" dalam Pasal 32 ayat (5) Undang-Undang tentang Partai Politik. Pembentuk Undang-Undang Partai Politik yang berasal dari anggota Partai Politik sendiri tidak cermat memahami konstruksi hukum keberadaan mahkamah Partai Politik dalam Undang-Undang Partai Politik. Dan ini membuka ruang bagi negara untuk terseret dalam konflik internal Partai Politik. Independensi kekuasaan kehakiman yang menjadi prinsip dasar kekuasaan kehakiman dalam Undang-Undang Kekuasaan Kehakiman menjadi tak berarti. Pasal 33 Undang- Undang tentang Partai Politik memaksa negara masuk ke dalam perselisihan partai melalui mekanisme judicial. ${ }^{34}$

\section{F. Kesimpulan}

1. Kewenangan penyelesaian perselisihan internal partai politik di indonesia diatur dalam pasal 32 Undang-Undang partai politik. Berdasarkan ketentuan pasal 32 tersebut jelas disebutkan secara prosedural bahwa jika terjadi perselisihan internal partai politik, maka secara ketentuan partai sebagaimana diatur dalam Anggaran Dasar (AD) maupun Anggaran Rumah Tangga (ART) penyelesaiannya diserahkan kepada mahkamah partai politik atau sebutan lain di setiap partai politik. Sedangkan penyelesaian konflik internal Partai Politik Lokal di Aceh yang berhubungan dengan konflik antara pimpinan dengan pimpinan, pimpinan dengan anggota dan anggota dengan anggota diselesaikan oleh Majelis Tuha Peut menurut tingkatan dan putusan Majelis Tuha Peut mengikat para pihak yang berselisih.

2. Kekuatan mengikat putusan yang dihasilkan oleh mahkamah partai politik dalam penyelesaian perselisihan internal partai politik dapat dilihat dari sifat putusan mahkamah partai politik yang bersifat final dan mengikat berdasarkan ketentuan Pasal 32 ayat (5) Undang-Undang Partai Politik, akan tetapi turut juga diselesaikan melalui Pengadilan Negeri dengan putusannya yang bersifat pertama dan terakhir dan hanya dapat mengajukan kasasi kepada Mahkamah Agung berdasarkan ketentuan Pasal 33 Undang-

34 http://www.negarahukum.com/hukum/negara-di-pusaran-konflik-partai-politik.html, diakses 11 Desember 2016, Pukul 21.39 Wib. 
Undang Partai Politik dan juga diperkuat dalam putusan Mahkamah Agung RI.

3. Putusan mahkamah Partai Politik bersifat terakhir dan mengikat (final and binding) untuk internal Partai Politik dalam hal perselisihan itu yang berkenaan dengan kepengurusan. Dengan adanya lembaga mahkamah Partai Politik tersebut Partai Politik dapat menyelesaikan sendiri perselisihan yang terjadi ditubuh partainya, dengan harapan tidak melibatkan negara dalam perselisihan tersebut. Namun, sayangnya disamping putusan mahkamah Partai Politik bersifat terakhir dan mengikat (final and binding) ternyata apabila setelah penyelesaian melalui mahkamah Partai Politik tidak tercapai Undang-Undang Partai Politik masih menyediakan sarana penyelesaian melalui Pengadilan Negeri. Seharusnya penyelesaian perkara yang berkenaan dengan kepengurusan Partai Politik cukup dengan putusan yang dikeluarkan oleh mahkamah Partai Politik dan tidak ada lagi upaya hukum selanjutnya.

\section{DAFTAR PUSTAKA}

\section{A. Buku}

Asshiddiqie, Jimly. Perkembangan dan Konsolidasi Lembaga Negara Pasca Reformasi. Jakarta: Sekretariat Jendral dan Kepaniteraan Mahkamah Konstitusi RI. 2006

Kemerdekaan Berserikat, Pembubaran Partai Politik dan Mahkamah Konstitusi. Jakarta: Sekretariat Jenderal dan Kepaniteraan MK RI. 2006 Perihal Undang-undang, Jakarta, Raja Grafindo 2011

Konstitusi dan Konstitusionalisme Indonesia. Jakarta: Konstitusi Press. 2006

Pengantar Ilmu Hukum Tata Negara. Jakarta: RajaGrafindo Persada. 2014 Peradilan Etik dan Etika Konstitusi. Jakarta Timur: Sinar Grafika. 2015

Pokok-Pokok Hukum Tata Negara Indonesia, Bhuana Ilmu Populer, Jakarta

Azed, Abdul Bahri dan Makmur Amir, Pemilu dan Partai Politik di Indonesia Jakarta: Pusat Studi Hukum Tata Negara Fakultas Hukum Universitas Indonesia, 2005

Budiharjo, Miriam. Dasar-Dasar Ilmu Politik, PT. Gramedia, Jakarta, 1977

Bartens K dan Nugroho, "Realita Sosial” Jakarta, Gramedia Pustaka : 1985

Bryan A. Gerner, Editor, 2009, Black's law Dictionary Ninth Edition, West Publishing Co.USA,

Chalid Narbuko dan Abu Ahmad, Metode Penelitian, Bumi Aksara, 2007 Jimly Asshiddiqie, Pokok-Pokok Hukum Tata Negara Indonesia, Bhuana Ilmu Populer, Jakarta, 2007

Cipro, Bambang.Prospek dan Tantangan Partai Politik. Yogyakarta: Pustaka Pelajar. 1996

F.A.M. Stroink dalam Abdul Rasyid Thalib, Wewenang Mahkamah Konstitusi dan Aplikasinya dalam Sistem Ketatanegaraan Republik Indonesia, Citra Aditya Bakti, Bandung, 2006 
Prodjodikoro, Wirjono.Asas-asas Ilmu Negara dan Politik. Bandung: Eresco1981

Philipus M. Hadjon, Tentang Wewenang, Makalah, Universitas Airlangga, Surabaya, tanpa tahun

Prajudi Admosudirjo,Hukum Administrasi Negara, Ghalia Indonesia, Jakarta, 1983

H.Hadari Nawawi, Metode Penelitian Sosial, Gajah Mada University Press, Yogyakarta, 1983

Indroharto,.Usaha Memahami Undang-Undang Tentang PTUN, Beberapa Pengertian Dasar Hukum Tata Negara, Sinar Harapan, Jakarta,1993

Jan Michiel Otto terjemahan Tristam Moeliono dalam shidarta, Moralitas Profesi Hukum Suatu Tawaran Kerangka Berfikir, Bandung: PT.Revika Aditama, 2006

Gaffar,Afan.Partai Politik dan Kelompok Kelompok Penekan. Yogyakarta: PT. Bina Aksara. 1984

Haryanto.Partai Politik Suatu Tinjauan Umum. Yogyakarta: Liberty. 1984

M.Solly Lubis, Filsafat Ilmu Hukum dan Penelitian, (Jakarta: PT.Sofimedia, 2012

Peter Mahmud Marzuki, Pengantar Ilmu Hukum, Jakarta: Kencana, 2008

Philipus M.Hajon dkk, Pengantar Hukum Administrasi Indonesia, Jokdjakarta: Gadjah Mada University Press, 2001

Philipus M. Hadjon, dkk, Hukum Administrasi Dan Tindak Pidana Korupsi, Gadjah Mada University Press, Yogyakarta, (Selanjutnya disebut Philipus II)

Hukum Administrasi Dan Tindak Pidana Korupsi, Gadjah Mada University Press, Yogyakarta, hlm.11. (Selanjutnya disebut Philipus II

Satjipto Raharjo, Mengejar Keraturan Menemukan Ketidakteraturan - teaching Order Finding Disorder, ( Pidato mengakhiri masa jabatan sebagai Guru Besar Tetap pada Fakultas Hukum Universitas Diponegoro, Semarang 15 Desember 2000

Suryono Sukanto \& Sri Mamudji, Penelitian Hukum Normatif, PT.Raja Grafindo Persada, Jakarta, 2001

Tubagus Ronny Rahman Nitibaskara, Paradoksal Konflik dan otonomi Daerah, Sketsa bayang-bayang Konflik Dalam Prospek Masa Depan Otonomi Daerah, 2002

Soedarsono, Mahkamah Konstitusi Sebagai Pengawal Demokrasi: Penyelesaian Sengketa Hasil Pemilu 2004 oleh Mahkamah Konstitusi RI, Jakarta: Sekretariat Jenderal dan Kepaniteraan Mahkamah Konstitusi RI, 2005

Franz Magnis dan Suseno, Etika Politik; Prinsip-Prinsip Moral Dasar Kenegaraan Modern, Cetakan Kelima, Gramedia Pustaka Utama, Jakarta, 1999

Fisher, R. 1964. Fractionating conflict. Dalam R. Fisher, ed. International conflict and behavioral science: the craigville papers. New York: Basic Books. 
Huntington, Samuel P.Tertib Politik Di Tengah Pergeseran Kepentingan Massa, Terjemahan dari Political Order in Changing Societies, Alih bahasa: Sahat Simamora dan Suryatim, Jakarta: RajaGrafindo Persada, 2003

Huda, Ni'matul, Hukum Tata Negara Indonesia, PT. Raja Grafindo Persada, Jakarta, 2005.

H. Hadari Nawawi, Metode Penelitian Sosial, Gajah Mada University Press, Yogyakarta, 1983.

Irfan Fachruddin, 2004, Pengawasan Peradilan Administrasi Terhadap Tindakan Pemerintah, Alumni, Bandung

Ramalan Surbakti, Memahami Ilmu Politik, Jakarta : PT. Gramedia Widiasarana : 1999

Rahman Arifin, "Sistem Politik Indonesia dalam Perspektif Struktural Fungsional" (Surabaya,SIC : 2002), hal. 184

Robbin Stephen P, Administrative Process : Integrating theory and practice, New Delhi, 1978

Romli, Lili.Islam Yes Partai Islam Yes, Sejarah Perkembangan Partai-Partai Islam di Indonesia. Jakarta: Pustaka Pelajar. 2006

Ridwan HR, Hukum Administrasi Negara, Jakarta: Rajawali Press, 2006

Hukum Administrasi Negara, Ed.Revisi-6, Rajawali Pers, Jakarta, 2011

Hukum Administrasi Negara, Edisi Revisi, Cetakan Ketujuh, (Jakarta: Rajagrafindo Persada, 2010

Soerjono Soekanto ,Sosiologi Suatu Pengantar, (Jakarta, Graha Grafindo : 1995)

Pengantar Penelitian Hukum ( Jakarta:UI Press 1986)

Slamet Santosa, Dinamika Kelompok, ( Jakarta, Bumi Aksara : 1999)

W. Sumardjono Pedoman Pedoman Pembuatan Usulan Penelitian Sebuah

Panduan Dasar, Jakarta: Gramedia Pustaka Utama, 2001

W. Friedman, “Legal Theory”, New York: Columbia University Press, 1967

Suwito, Dwi Darojatun Patra.Perselisihan Internal Partai Politik Dalam Berbagai Putusan Pengadilan. Jakarta: Adhi Sarana Nusantara. 2016 Aspek Hukum Perselisihan Internal Partai Politik. Jakarta: Adhi Sarana Nusantara. 2017

\section{B. Tesis /Jurnal / Skripsi /Makalah / Artikel / Majalah / Koran}

Asshiddiqie, Jimly, 2006, Partai Politik dan Pemilihan Umum Sebagai Instrumen Demokrasi, Jurnal Konstitusi, Volume 3 Nomor 4, Desember.

Agustina Fitria, Kedudukan Mahkamh Partai Politik Dalam Penyelesaian Sengketa Internal Berdasarkan Undang-Undang Nomor 2 Tahun 2011, Skripsi, Fakultas Hukum Universitas Jember, 2015

David Julius Sarusuk, "Analisis Keberadaan Mahkamah Partai Politik di Indonesia Dalam Penyelesaian Perselisihan Internal Partai Politik" Skripsi, Fakultas Hukum Universitas Sumatera Utara, 2018.

Departemen Pendidikan Nasional, Kamus Besar Bahasa Indonesia Pusat Bahasa Edisi Keempat, Gramedia Pustaka Utama, Jakarta, 2014 
Maya Rizki Perdana,“ Kewenangan Mahkamah Partai Sebagai Lembaga Penyelesaian Sengketa Internal Partai Politik" Skripsi Fakultas Hukum Universitas Andalas, 2016

Herman, Sistem Kepartaian di Indonesia dilihat dari Model Laakso Taagepara dan Indeks Rae dan Kaitannya dengan Ketahanan Nasional Program Kajian Strategik Ketahanan Nasional, Jakarta : Program Pasca Sarjana Universitas Indonesia, 2009

Gayus T. Lumbun, 2006, Asas-Asas Umum Pemerintahan Yang Baik Dalam Perspektif Hukum Admistrasi Negara Ditinjau Dari Aspek Kegunaan Dan Manfaat, Pidato Pengukuhan Sebagai Guru Besar Besar Tetap Dalam Bidang Ilmu Hukum Administrasi Negara Fakultas Hukum Universitas Krisna Dwipayana, Jakarta,2006

Indra, Mexsasai, Gagasan Peyederhanaan Jumlah Partai Politik Dihubungka Dengan Sistem Pemerintahan Republik Indonesia, Jurnal Ilmu Hukum Volume 2, Nomor 2.tahun 2006

L., Debora Sanur, 2015. "Manajemen Konflik Partai Politik", Jurnal Info Singkat, Vol. VII, No.07/I/P3DI/April/2015, Jakarta: Pemerintahan Dalam Negeri.

Tri Cahya Indra Permana, Model Penyelesaian Perselisihan Partai Politik secara internal maupun eksternal, Jurnal Hukum dan Peradilan, Volume 5, 2016.

Junus Damanik, Kewenangan Kepolisian Terhadap Pemberantas Tindak Pidana Korupsi Setelah berlaku Undang-Undang Nomor 10 Tahun 2002 Tentang Korupsi Tindak Pemberantas Korupsi, Tesis Magister Hukum Universitas Malikussaleh Tahun, 2018.

Ridwan, Diskresi \& Tanggung Jawab Pemerintah, FH UII Press, Yogyakarta, 2014. (Selanjutnya disebut Ridwan II)

Kamus Besar Bahasa Indonesia Pusat Bahasa, Edisi Keempat, Departemen Pendidikan Nasional, Jakarta, 2008.

Moh. Mahfud MD, Penegakan Hukum DanTata Kelola Pemerintahan Yang Baik, Bahan pada Acara Seminar Nasional "Saatnya Hati Nurani Bicara" yang diselenggarakan oleh DPP Partai HANURA. Mahkamah Konstitusi Jakarta, 8 Januari 2009.

Firdaus, Kekuatan Keputusan Mahkamah Partai Ditinjau dari Sistem Kekuasaan Menurut UUD 1945, Jurnal Konstitusi, Volume 14, Nomor 3, September 2017 Fakultas Hukum Universitas Sultan Ageng Tirtayasa Banten.

\section{Peraturan Perundang-Undangan}

Undang-Undang Dasar Negara Republik Indonesia Tahun 1945

Undang-Undang Republik Indonesia Nomor 2 Tahun 2011 Tentang Perubahan Atas Undang-Undang Nomor 2 Tahun 2008 Tentang Partai Politik.

Undang-Undang Republik Indonesia Nomor. 11 Tahun 2006 Tentang Pemerintah Aceh

Peraturan Pemerintah Nomor. 22 Tahun 2007 tentang Partai Politik Lokal. 